\title{
Debate about compulsory cremation of victims of COVID-19
}

\section{- Position Paper by the College of Community Physicians of Sri Lanka}

\section{The College of Community Physicians of Sri Lanka}

Author group composed of Major Contributors: Ruwan Ferdinando ${ }^{1} \&$ Suneth Agampodi ${ }^{2}$; Reviewers: Anuji Gamage $^{3}$, Ishanka Talagala ${ }^{4}$, Carukshi Arambepola ${ }^{5}$, Shamini Prathapan ${ }^{6}$ Nihal Abeysinghe $^{7}$

${ }^{1}$ National Institute of Health Sciences, Ministry of Health and Indigenous Medical Services, Sri Lanka; ${ }^{2}$ Rajarata University of Sri Lanka; ${ }^{3}$ General Sir John Kotelawala Defence University; ${ }^{4}$ Disaster Preparedness and Response Unit, Ministry of Health and Indigenous Medical Services, Sri Lanka; ${ }^{5}$ University of Colombo, Sri Lanka; ${ }^{6}$ University of Sri Jayewardenepura, Sri Lanka; ${ }^{7}$ Institute for Research and Development in Health and Social Care, Colombo, Sri Lanka

*Correspondence: ruwanferdinando@gmail.com

DOI: https://doi.org/10.4038/jccpsl.v26i4.8403

Received on 30 December 2020

Accepted on 31 December July 2020

\section{Background}

The global impact of the ongoing COVID-19 pandemic has been devastating and at the same time it has brought to the fore a number of hitherto unheard social and cultural issues. There are cultural implications of COVID-19 in relation to disease spread, case detection, treatment, prevention \& control and also in relation to management of dead bodies. These complex interactions may create situations which may adversely affect the pandemic control activities. The present guidelines on safe disposal of dead bodies of person infected with SARS-CoV-2 virus in Sri Lanka have created such a situation.

The Ministry of Health Provisional Clinical Practice Guidelines on COVID-19 Suspected and Confirmed Patients dated 27th March 2020 allowed for burial of dead bodies under certain conditions. However, the subsequent versions from 31st March onward and the current version (1) require that all COVID-19 victims be cremated. The Extraordinary Gazette notification https://orcid.org/0000-0002-6123-5634

2170/8 of April 11 of the Democratic Socialist Republic of Sri Lanka, has amended the regulations made by the Minister of Health and Indigenous Medical Services under Section 2 and 3 of the Quarantine and Prevention of Diseases Ordinance (Chapter 222) to include the following: "Cremation of Corpse of a person who has died of Coronavirus Disease 2019 (COVID-19) - Notwithstanding the provisions of regulations 61 and 62, the corpse of a person who has died or is suspected to have died, of Coronavirus Disease 2019 (COVID-19) shall be cremated..." (2). At present, all dead bodies of COVID-19 confirmed or suspected persons should be cremated. This practice has become a major concern in some communities, which are affected by COVID19 , more than others.

COVID-19 is a rapidly evolving situation during which the decision making would have to be based on precautionary principles at the early stage of the pandemic. However, with the accumulation of further evidence, it empowers us to rethink and revise the recommendations. This position paper is intended to 
voice a scientific opinion in this debate after examining the currently available evidence. However, it should be noted that this position could change depending on new evidence and observations which will surface in the future.

\section{The infection risk from COVID-19 dead bodies}

The latest scientific brief updated in October 2020 by the National Center for Immunization and Respiratory Diseases (NCIRD), Division of Viral Diseases, Center for Disease Control clearly confirms that the spread of SARS-CoV-2 is primarily through respiratory droplets. Contact transmission and air-borne transmission are also possible but not the main mode of transmission (3). This updated scientific brief is compatible with the evidence summary published in July 2020 by the WHO (4) and there is no change in the evidence on the transmission of SARS-CoV-2 virus with more than 80 million global cases and 1.7 million deaths.

With more than 85,000 published scientific literature on COVID-19, not a single case has been reported due to virus transmitted through a dead body. A report published in May 2020 suggested that two forensic medicine professionals contracted COVID-19 from a corpse (5), but later an erratum was published by the authors confirming that it was not on a case of confirmed transmission of COVID-19 from corpse (6).

The claims on the SARS-CoV-2 spread directly through groundwater have not been scientifically substantiated and there is no indication that the virus could be transmitted through drinking water (7). As per the viral biology, these viruses need a host cell to survive for a long period. On the other, there are scientific methods available that could be adopted to minimize such effects viz. insulation, leachate collection and treatment. The principal sources and routes of potential transmission of SARS-CoV-2 in water systems could be hospital sewage, waste from isolation and quarantine centers, faecal-oral transmission, contaminated surface and groundwater sources and contaminated sewage (8), but not the dead bodies. Coronaviruses die off rapidly in wastewater at $230 \mathrm{C}$, within 2 to 4 days and the process is rapid in higher temperatures as in Sri Lanka (9).

The risk of COVID-19 from the human remains/ dead bodies has been discussed in almost all public health programmes around the world. Two systematic reviews on dead body management during global pandemic of COVID-19 clearly show that there is no evidence on COVID-19 transmission so far from dead bodies (10-11). However, the duration of viral survival in dead body is still debatable and WHO, $\mathrm{CDC}$ and the European Center for Disease Prevention and Control had issued clear and extensive guidelines on handling dead bodies confirmed or suspected as having COVID-19 with detailed attention to the procedures in relation to handling the body in the ward, mortuary, funeral home, during transfer, and crematorium /burial site. At the same time these guidelines strongly discourage any ritual practice which may involve in risk of disease transmission. Nevertheless, all these global pandemic control programmes clearly stipulate that the victims can be "buried or cremated" with all precautions mentioned earlier.

\section{Impact of cultural issues on the COVID-19 control activities}

Due to the highly contagious nature of this disease and the resulting quarantine and lockdown, it is natural that the fear associated with the disease is also rising when the disease is fast spreading, affecting the well-being of people. Anxiety, preoccupation with thoughts of Coronavirus infection, paranoia with getting infected, disease-related social media have been found as common manifestations of this fear psychosis. Biological disasters like this pandemic can generate immense prejudice, xenophobia, stigma and othering, all of which have adverse consequences on health and well-being (12) and in the public participation in the control programme.

COVID-19 pandemic has taught the world many lessons: one is about the importance of collective responsibility vs. individual responsibility in shaping the wellbeing of all. A proper COVID-19 control 
strategy has to be all inclusive, lest, could end up in endangering the lives of all. This is the true meaning of Whole-of-Government, Whole-of-Society approach. A scientific cost benefit evaluation is required in culturally sensitive issues which might affect participation of some communities in disease control activities such as getting engaged in early detection, contact tracing, volunteering with correct information and in seeking healthcare.

\section{Conclusion}

There is no solid evidence indicating that burial of dead bodies would increase the spread of the disease. With the available scientific evidence and the impact of the decision on cremation on pandemic control activities at large, CCPSL concludes that adhering to global guidelines (13-15), each citizen of Sri Lanka should be allowed to be cremated or buried as per his/her and the family's desire within the strict guidelines recommended by the Ministry of Health.

Fear, xenophobia and collectivism as predictors of well-being during Coronavirus disease 2019: An empirical study from India. International Journal of Social Psychiatry, 0020764020936323.Evaluation is a systematic and impartial assessment employed by stakeholders mainly to assess the effectiveness and efficiency of a given intervention like an activity, project, programme, strategy, or policy (1). Two key purposes of evaluation are accountability and learning. Accountability includes being accountable for the resources spent: whether resources are being optimally utilized and to what extent the intended results were achieved. Learning component of evaluation provides evidence for evidence-based decision making in the planning process. Evaluators are interested in finding out 'what worked' and 'how it worked' to help decision makers to learn from the best practices of the success stories. However, learning from failures- 'what failed' and 'why it failed'- is also essential to avoid repetition of the same mistake in future (1).

\section{References}

1. Epidemiology Unit. Provisional Clinical Practice Guidelines on COVID-19 Suspected and Confirmed Patients. Colombo: Ministry of health, Sri Lanka. Available from: https://www.epid.gov.lk/ web/images/pdf/Circulars/Corona_virus/covid19_cpg_version_5.pdf.

2. Quarantine and Prevention Of Diseases Ordinance (Chapter 222). Available from: http://www. documents.gov.lk/files/egz/2020/4/2170-08_E.pdf.

3. CDC. Scientific Brief: SARS-CoV-2 and potential airborne transmission. National Center for Immunization and Respiratory Diseases (NCIRD), Division of Viral Diseases, CDC, 10th November 2020. Available from: https://www.cdc.gov/ coronavirus/2019-ncov/more/scientific-brief-sarscov-2.html.

4. WHO. Coronavirus disease (COVID-19): How is it transmitted? World Health Organization, 9th July 2020. Available from: https://www.who.int/ emerge ncies/diseases/novel-coronavirus-2019/questionand-answers-hub/q-a-detail/ corona virus-diseasecovid-19-how-is-it-transmitted.

5. Sriwijitalai W, Wiwanitkit V. COVID-19 in forensic medicine unit personnel: observation from Thailand. Journal of Forensic and Legal Medicine 2020; 72: 101964. doi: 10.1016/j.jflm.2020.10196 4.

6. Sriwijitalai W, Wiwanitkit V. Corrigendum to COVID-19 in forensic medicine unit personnel: Observation from Thailand. Journal of Forensic and Legal Medicine 2020; 72: 101967. doi: 10.1016/j.jflm.2020.101967.

7. WHO. Water, sanitation, hygiene, and waste management for SARS-CoV-2, the virus that causes COVID-19. World Health Organization, 29th July 2020. Available from: https://www.who.int/ publications/i/item/WHO-2019-nCoV-IPCWASH-2020.4.

8. Sunkari ED, Korboe HM, Abu M, Kizildeniz T. Sources and routes of SARS-CoV-2 transmission in water systems in Africa: are there any sustainable remedies? Science of the Total Environment 2021; 753: 142298. doi: 10.1016/j.scitotenv.2020. 142298. PMC7480675.

9. Gundy PM, Gerba CP, Pepper IL. Survival of coronaviruses in water and wastewater. Food and Environmental Virology 2009; 1(1): 10. 
10. Vidua RK, Duskova I, Bhargava DC, Chouksey VK, Parthasarathi P. Dead body management amidst global pandemic of Covid-19. MedicoLegal Journal 2020. 0025817220926930.

11. Yaacoub Sally, et al. Safe management of bodies of deceased persons with suspected or confirmed COVID-19: a rapid systematic review. BMJ Global Health 2020; 5.5: e002650.
12. Ahuja, KK, Banerjee D, Chaudhary K, Gidwani C. Fear, xenophobia and collectivism as predictors of well-being during Coronavirus disease 2019: an empirical study from India. International Journal of Social Psychiatry 2020. 0020764020936323. 